\title{
Bazı Ekmeklik Buğday (Triticum aestivum L.) Çeşit ve Hatlarında SPAD Metre ve NDVI Ölçümlerinin Kalite Özellikleriyle İlişkilerinin Biplot Analiz Yöntemi ile Değerlendirilmesi
}

\section{Determining the Relationship of SPAD Reading and NDVI with Quality Traits of Bread Wheat by Biplot Analysis}

\author{
${\text { Merve Bayhan }{ }^{1 *} \text {, Önder Albayrak }{ }^{2}, \text { Remzi Özkan }^{3}, \text { Cuma Akıncı }^{4} \text {, Mehmet Yıldırım }}^{5}$
}

Geliş / Received: 11/11/2020

Revize / Revised: 14/12/2020

Kabul / Accepted: 23/12/2020

\section{$\overline{\mathbf{O Z Z}}$}

Parçalanan ve azalan tarım alanlarından elde edilen üretimle günümüzde hızla artan nüfusun, yeterli ve dengeli beslenmesi imkânı her geçen gün daha da zorlaşmaktadır. Bu nedenle artan besin ihtiyaçlarının karşılanmasında değişen ekolojik koşullaraiyi uyum gösteren, morfolojik ve fizyolojik yönden uygun, verim ve kalite özellikleri iyi olan genotiplerin belirlenmesi büyük önem taşımaktadır. Bu çalışmada Diyarbakır koşullarına uyum sağlamada bazı ekmeklik buğday (Triticum aestivum L.) genotiplerinde fizyolojik özelliklerden NDVI (normalleştirilmiş vejetasyon farklılık indeksi) ve SPAD (klorofil içeriği) ile bazı kalite özellikleri (protein oranı, nişasta oranı, yaş gluten oranı, zeleny sedimantasyon değeri ve hektolitre ağırlığı) incelenmiştir. Çalışma, Diyarbakır'da Dicle Üniversitesi Ziraat Fakültesi Tarla Bitkileri Bölümü araştırma ve uygulama alanında 20182019 üretim sezonunda yağışa dayalı koşullarda yürütülmüştür. Deneme, tesadüf blokları deneme desenine göre 3 tekerrürlü olarak kurulmuştur. Çalışmada materyal olarak bölgede yoğun olarak yetiştirilen 4 adet ticari çeşit (Dinç, Ceyhan 99, Empire ve Pehlivan) ve CIMMYT (Uluslararası Mısır ve Buğday Geliştirme Merkezi)'ten temin edilen 16 adet ileri ekmeklik buğday hatı kullanılmıştır. SPAD ölçümlerinin protein, glüten ve sedimantasyonla ilişkili olduğu belirlenmiştir. Ayrıca SPAD ve NDVI ölçümleri bitkinin farklı gelişim dönemlerinde doğru bir şekilde alındığında ıslah çalışmalarında seleksiyon kriteri olarak ele alınabileceği sonucuna varılmıştır. Fizyolojik ve kalite özellikleri bakımından DZ20-E6 hatının standart çeşitlere ve diğer hatlara üstünlük sağlamıştır.

\section{Anahtar Kelimeler-Ekmeklik Buğday, Biplot Analizi, Fizyolojik, Kalite}

\footnotetext{
1*Sorumlu yazar iletişim: mervebayhan21@gmail.com (https://orcid.org/0000-0002-3220-4548)

Tarla Bitkileri Bölümü, Dicle Üniversitesi, Sur, Diyarbakır

2İletişim: ondera@dicle.edu.tr (https://orcid.org/0000-0003-2440-7748)

Tarla Bitkileri Bölümü, Dicle Üniversitesi, Sur, Diyarbakır

3̇letişim: rmziozkan@gmail.com (https://orcid.org/ 0000-0002-6457-5802)

Tarla Bitkileri Bölümü, Dicle Üniversitesi, Sur, Diyarbakır

4İletişim: akinci@dicle.edu.tr (https://orcid.org/ 0000-0002-3514-1052)

Tarla Bitkileri Bölümü, Dicle Üniversitesi, Sur, Diyarbakır

İletişim: mehmety@dicle.edu.tr (https://orcid.org/ 0000-0002-6953-4479)

Tarla Bitkileri Bölümü, Dicle Üniversitesi, Sur, Diyarbakır
} 


\section{ABSTRACT}

It is becoming more and more difficult for the rapidly increasing population to have adequate and balanced nutrition with the production obtained from the fragmented and decreasing agricultural areas. Therefore, it is of great importance to determine genotypes that are well adapted to the changing ecological conditions of the region, morphologically and physiologically appropriate; yield and quality characteristics are good in meeting the increasing nutritional needs. In this study, physiological properties, such as NDVI (normalized vegetation difference index) and SPAD (chlorophyll content) and some quality properties (protein content, starch content, wet gluten content, zeleny sedimentation value and hectoliter weight) in some bread wheat Triticum aestivum L.) genotypes under Diyarbakır conditions were investigated. The study was carried out in the research and application area of Dicle University Faculty of Agriculture in Diyarbakır in rainy conditions during the 20182019 production season. The experiment was designed as randomized block design with 3 replications. In this study, materials were used as follows: four check cultivars (Dinç, Ceyhan 99, Empire and Pehlivan) which are grown intensively in the region and 16 advanced bread wheat lines obtained from CIMMYT (International Maize and Wheat Improvement Center). It was determined that SPAD measurements were associated with protein, gluten, and sedimentation parameters. In addition, it was concluded that when SPAD and NDVI measurements are taken correctly in different growth stages of the plant, it can be considered as selection criteria in breeding studies. DZ20-E6 lines in terms of physiological properties and quality characteristics have superiority over standard varieties and other lines.

\section{Keywords-Bread Wheat, Biplot Analysis, Physiological, Quality}

\section{GíRiş}

Önemli bir kültür bitkisi olan buğday, hem ekiliş alanı olarak hem de üretim miktarı bakımından dünyada ve Türkiye'deilk sıralarda yer almaktadır. Buğday, insanlar için gıda ürünü olmasının yanında hayvan beslenmesinde de kullanılmaktadır. Dünya'da 216.2 milyon hektar buğday ekilip, 735 milyon ton ürün elde edilmektedir [1]. Türkiye'debuğday ekim alanı 7.6 milyon hektar olup, üretimi ise 20 milyon tondur.Türkiye'de1.2 milyon ha ekim alanıyla buğday üretiminde önemli bir paya sahip olan Güneydoğu Anadolu Bölgesi buğday ekim alanlarımızın yaklaşık \% 16'sını oluşturmaktadır. Bölgede, ekmeklik buğdayın buğday ekim alanı içerisindeki payının \% 30-40 olduğu tahmin edilmekte ve buğday ekim alanının \% 24'ünün Diyarbakır ilinde yer aldığı bildirilmektedir [2].

Son yıllarda buğdayda verim ve kaliteye katkıda bulunan fizyolojik özellikler 1slah yöntemlerine dahiledilerek çeşit geliştirme faaliyetleri gerçekleştirilmektedir. Bu fizyolojik özelliklerin belirlenmesi için hızlı, basit, ucuz ve bitkiye zarar vermeden ölçüm yapabilen SPAD metre, termal kamera, NDVI (Normalleştirilmiş Vejetasyon Farklılı İndeksi), (Greenseeker) ve yaprak alanı indeksi gibi spektral yansıtma cihazları kullanılmaktadır. Islah çalışmalarındaki temel hedef, verimlilik ve kalite özelliklerini geliştirmek üzerine oluşmuştur. Yetiştirme çalışmalarındaki farklılıkların belirlenmesinde birçok gözlem, ölçüm ve yöntem kullanılmaktadır. Bu yöntemlerin etkili, sürdürülebilir, güvenilir, zaman kazandıran ve uygulaması kolay olmalıdır. Uzaktan algılama yöntemleri bu amaçlar için geliştirilmiştir ve hassas tarımsal uygulamaların önemli bir bileşenidir. Bitki büyümesini, bitki biyokütlesini, yaprak alan indeksini (LAI), azot (N) içeriğini ve tane verimi tahminlerini izlemek için kullanılan bu sistemler hızlı olup bitki kesilmesine gerek duyulmaz [3]. NDVI, tane verimini tahmin etmek için kullanılan en yaygın spektral indekstir. NDVI klorofilin kızılötesi enerjiye yakın yansıma ve kırmızı 1şı̆̆ı emme kabiliyeti nedeniyle, yaprak yoğunluğu yüksek olan alanların nispeten az yapraklı alanlardan ayrılmasını sağlamaktadır. Aynı zamanda NDVI, bitki örtüsü değişimi, bitki örtüsü sınıflandırması ve bazı parametrelerin hesaplanmasında oldukça başarılı olduğu kanıtlanan bitki örtüsü endeksidir. Özellikle çiçeklenme ve tane dolum döneminde NDVI'nın tane verimi ile güçlü korelasyon ilişkisi bulunmaktadır [4].

Spektral yansıtma bazlı çalışan SPAD metre, tane verimi artırma endeksli yapılan ıslah çalışmalarında bitki ıslahçıları tarafından yoğun olarak kullanılmaktadır.SPAD metre cihazı yaprakta mevcut klorofil ve azot miktarını dolaylı bir şekilde ölçebilmektedir.SPAD metre, kullanımı kolay, maliyetinin ucuz olmasının yanı sıra, taşınabilir olması ve ölçüm yapılırken yaprağa zarar vermemesi özellikleri ile son zamanlarda yapılan birçok 


\begin{tabular}{|c|c|c|}
\hline & $\begin{array}{l}\text { BŞEÜ Fen Bilimleri Dergisi } \\
8(1), 32-41,2021\end{array}$ & $\begin{array}{r}\text { BSEU Journal of Science } \\
\text { https://doi.org/10.35193/bseufbd.824421 }\end{array}$ \\
\hline $\begin{array}{l}\text { BïLECEKSEYH EDEE } \\
\text { UNIVERSITTE }\end{array}$ & & 2458-7575 (https://dergipark.org.tr/tr/pub/bseufbd) \\
\hline
\end{tabular}

çalışmalarda kullanılmıştır.Bavec ve Bavec (2001) [5], yaptıkları çalışmada SPAD değeri ile tane verimi arasında başaklanma, tane dolum dönemlerinde önemli ve olumlu ilişkiler saptamışlardır.

Ülkemizde yabancı ot, hastalık, zararlılar, kuraklık ve tuzluluk vb. etmenler buğdayda verim ve kaliteyi ciddi oranda olumsuz etkilemektedir. Bu olumsuz etmenler ile mücadele edebilecek yeni buğday çeşitlerin geliştirilmesi bitki ıslahçıları açısından zorunlu olmaktadır.

Biplot analizi, iki yönlü bir tablo tasarımı olup, satır ve sütun faktörlerini grafiksel olarak göstermektedir. $\mathrm{Bu}$ analiz metodunda satır ve sütun faktörlerinin hem tek tek kendi arasındaki ilişkileri hem de ikili interaksiyonları görsel olarak sergilenebilmektedir. Biplot analizi ile genotiplerin çok sayıda özellik ve çevrede iki yönlü veri analizi yapılabilmektedir [6].

Yapılan bu çalışmada, Diyarbakır'da yetiştirilen bazı ekmeklik buğday çeşitleri ile ileri kademe ekmeklik buğday hatlarında fizyolojik parametreler ile kalite özellikleri arasındaki ilişkileri biplot analiz yöntemi ile saptanması amaçlanmıştır.

\section{MATERYAL VE METOT}

Bu çalışma, 2018-2019 buğday yetiştirme sezonunda Diyarbakır'da Dicle Üniversitesi Ziraat Fakültesi araştırma ve uygulama sahasında yağışa dayalı şartlarda yürütülmüştür. Araştırmada materyal olarak bölgede yoğun olarak yetiştirilen 4 adet ticari çeşit (Dinç, Ceyhan 99, Empire ve Pehlivan) ve CIMMYT (Uluslararası Mısır ve Buğday Geliştirme Merkezi)'ten temin edilen 16 adet ileri ekmeklik buğday hatı kullanılmıştır. Çalışmanın yürütüldüğ̈̈ 2018-2019 sezonu ve uzun yıllara ait bazı iklim verileri Şekil 1'de verilmiştir.

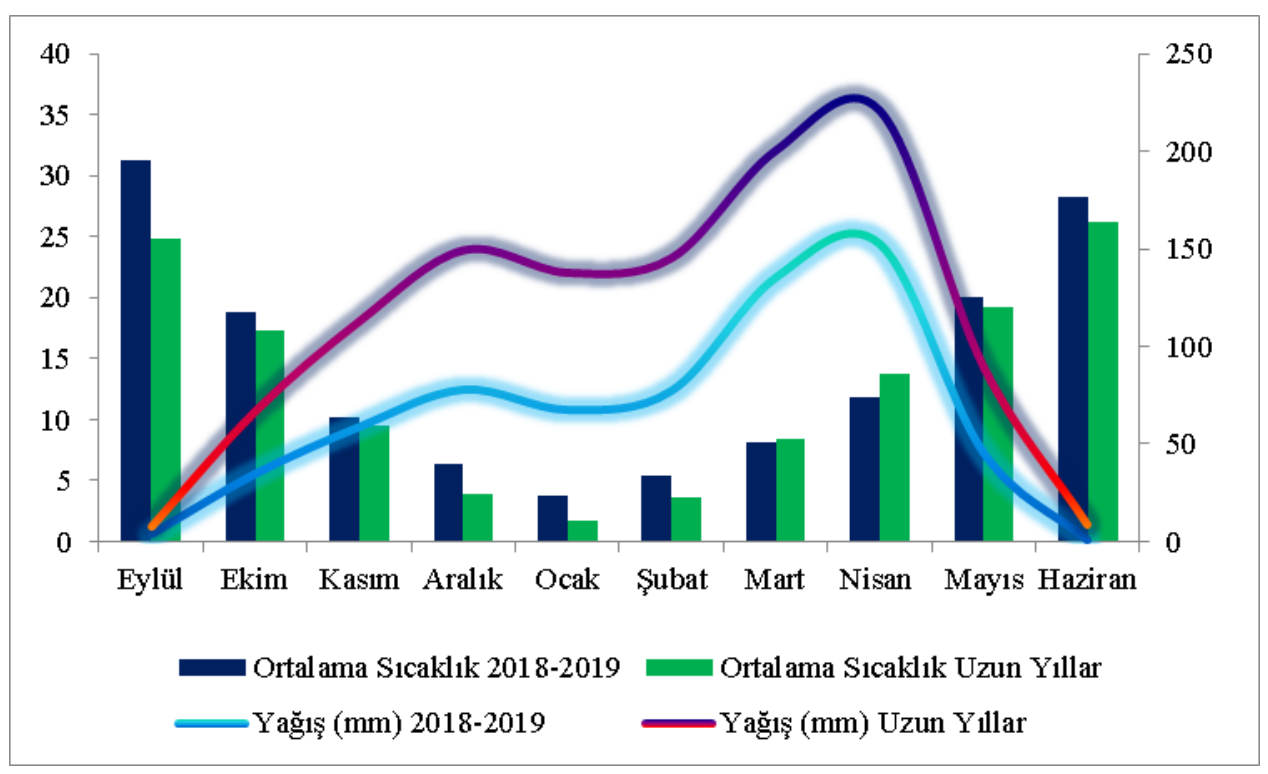

Şekil 1. Denemenin kurulduğu yıllara ilişkin iklim verileri

Deneme tesadüf blokları deneme desenine göre üç tekerrürlü olarak kurulmuştur. Denemede her parsel $1.2 \mathrm{~m} \mathrm{x} 4 \mathrm{~m}=4.8 \mathrm{~m}^{2}$ olacak şekilde ayarlanmıştır. Ekim işlemi metrekareye 500 tohum hesabıyla 5 Şubat tarihinde deneme mibzeri ile yapılmıştır. Ekimle birlikte, taban gübresi olarak $6 \mathrm{kgda}^{-1}$ saf azot (N) ve $6 \mathrm{kgda}^{-}$ ${ }^{1}$ saf fosfor $\left(\mathrm{P}_{2} \mathrm{O}_{5}\right)$ uygulanırken, $6 \mathrm{kgda}^{-1}$ saf azot $(\mathrm{N})$ ise sapa kalkma periyodunda üst gübre olarak verilmiştir. Yabancı otlarla mücadelede herbisit kullanılmıştır. Hasat işlemi parsel biçerdöveri ile $3.8 \mathrm{~m}^{2}$ lik alana denk gelecek şekilde 17 Temmuz 2019 tarihinde gerçekleştirilmiştir.

Araştırmada kullanılan fizyolojik ölçümlerden NDVI, yakın kızılötesi (NIR) ve görünür kırmızı (RED) bantlar arasındaki kontrastı arttırmak veya iki banttan tek bir bant halinde bilgi toplamak ve alandaki bitki varlığını incelemek için kullanılır [7].NDVI okumaları bitkiler başaklanma döneminde iken 0.00-0.99 değerleri aralığında ölçüm yapan Trimple Greenseeker cihazı ile açık havada rüzgarın olmadığı 11:00-14:00 saatleri arasında yapılmıştır.SPAD değeri, yaprakta bulunan klorofil miktarını ifade etmektedir. SPAD metre (Minolta 


\begin{tabular}{|c|c|c|}
\hline & $\begin{array}{l}\text { BŞEÜ Fen Bilimleri Dergisi } \\
8(1), 32-41,2021\end{array}$ & $\begin{array}{r}\text { BSEU Journal of Science } \\
\text { https://doi.org/10.35193/bseufbd.824421 }\end{array}$ \\
\hline $\begin{array}{l}\text { KSSEYHEDE } \\
\text { ERSIT }\end{array}$ & & 2458-7575 (https://dergipark.org.tr/tr/pub/bseufbd) \\
\hline
\end{tabular}

SPAD-502, Osaka, Japan) ile parseldeki bitkileri başaklanma (GS 55) dönemindeyken bitkinin bayrak yaprağında sabah 10-12 ve ögleden sonra 14-16 saatleri arasında açık havada ölçüm alınmıştır. Protein oranı $(\%)$, yaş gluten oranı (\%), nişasta oranı (\%), hektolitre ağırlı̆̆ $(\mathrm{kg} / \mathrm{hl})$ ve Zeleny sedimantasyon (ml) değerlerini belirlemek için taneler öğütme işlemine tabi tutulmadan NIR System Infratec 1241 Grain Analyzer (Foss, Hillerod, Danimarka) cihazıyla ölçülmüştür $[8,9]$.

Çalışma sonunda elde edilen değerler Tesadüf Blokları Deneme Desenine göre JUMP Pro 13 (SAS Institute Inc., US) istatistik paket programı yardımılla varyans analizine tabi tutulmuş ve ortalamalar arasındaki istatistiki farklılıklar LSD testi ile ortaya konmuştur [10]. Biplot analizleri ise GGE Biplot istatistik paket programı kullanılarak gerçekleştirilmiştir [11].

\section{BULGULAR VE TARTIŞMA}

Yapılan varyans analizinde; çeşitler arasında incelenen özellikler bakımından istatistiki olarak önemli görülen $(\mathrm{P}<0.01, \mathrm{P}<0.05)$ farklılıklar Tablo 1'de verilmiştir.

Genotiplere ait NDVI değerleri 0.53 ile 0.67 arasında değişim gösterirken, denemeye ait ortalama NDVI değerinin 0.61 olduğu tespit edilmiştir. NDVI değeri bakımından en yüksek değer \%0.67 ile DZ20-E3 hatından ve Pehlivan (\%0.67) kontrol çeşidinden elde edilirken, en düşük değer ise \%0.53 ile DZ20-E9 genotipinden elde edilmiştir. Yüksek NDVI değerleri sağlıklı bitki gelişimini göstermektedir [12].Crusiol ve ark.(2017) [13], NDVI değerinin ölçüm aşaması (kardeşlenme, sapa kalkma, başaklanma ve sonrası) ölçüm aralığı (günün farklı saatleri arasında) sensörün kullanım mesafesi (yüksekliği) ve çevre gibi birçok faktörden etkilendiğini bildirmiştir.Kızılgeçi ve ark.(2017) [14], bazı tritikale genotiplerinde fizyolojik parametrelerin verim ve kalite özellikleri üzerine etkisini belirlemek amacıyla iki farklı lokasyonda yaptıkları çalışmada; başaklanma döneminde ölçülen NDVI değerlerinin Diyarbakır lokasyonunda 0.77-0.81 arasında olduğunu, Mardin lokasyonunda ise 0.72-0.77 arasında değiştiğini bildirmişlerdir.Kızılgeçi ve Yıldırım (2019) [15], başaklanma döneminde ölçülen NDVI değerlerinin 0.42-0.85 arasında değiştiğini bildirmişlerdir.

Tablo 1. Araştırmada incelenen ekmeklik buğday genotiplerine ait ortalamalar ve oluşan gruplar

\begin{tabular}{|c|c|c|c|c|c|c|c|}
\hline Genotip & $\begin{array}{l}\text { NDVI } \\
\text { Değeri }\end{array}$ & $\begin{array}{l}\text { SPAD } \\
\text { Değeri }\end{array}$ & $\begin{array}{c}\text { Protein } \\
\text { Oranı (\%) }\end{array}$ & $\begin{array}{c}\text { Nişasta } \\
\text { Oranı }(\%)\end{array}$ & $\begin{array}{c}\text { Hektolitre } \\
\text { Ağırlığı } \\
\text { (kg/hl) }\end{array}$ & $\begin{array}{l}\text { Yaş Gluten } \\
\text { Oranı (\%) }\end{array}$ & $\begin{array}{c}\text { Zeleny } \\
\text { Sedimantasyon } \\
\text { Değeri }(\mathrm{ml})\end{array}$ \\
\hline DZ20-E1 & $0.62 \mathrm{a}-\mathrm{c}$ & 39.90 a-e & $16.86 \mathrm{~b}$ & $62.22 \mathrm{gh}$ & $78.48 \mathrm{f}-1$ & $33.34 \mathrm{a}-\mathrm{c}$ & $51.79 \mathrm{ab}$ \\
\hline DZ20-E2 & $0.63 \mathrm{a}-\mathrm{c}$ & 45.67 a & $15.25 \mathrm{~d}-\mathrm{g}$ & $61.91 \mathrm{~h} 1$ & 80.16 b-g & $30.92 \mathrm{~cd}$ & $50.46 \mathrm{a}-\mathrm{d}$ \\
\hline DZ20-E3 & $0.61 \mathrm{~b}-\mathrm{d}$ & $44.60 \mathrm{ab}$ & $15.90 \mathrm{c}-\mathrm{e}$ & $61.46 \mathrm{j}$ & $77.39 \mathrm{1j}$ & $32.37 \mathrm{a}-\mathrm{d}$ & $50.42 \mathrm{a}-\mathrm{d}$ \\
\hline DZ20-E4 & 0.67 a & $35.90 \mathrm{de}$ & $14.56 \mathrm{f}-1$ & $60.08 \mathrm{k}$ & $75.93 \mathbf{j}$ & $29.08 \mathrm{~cd}$ & $43.62 \mathrm{f}$ \\
\hline DZ20-E5 & $0.63 \mathrm{a}-\mathrm{c}$ & $37.87 \mathrm{~b}-\mathrm{e}$ & $14.63 \mathrm{f}-1$ & $63.29 \mathrm{bc}$ & $81.81 \mathrm{a}-\mathrm{c}$ & $29.99 \mathrm{~cd}$ & $47.10 \mathrm{~d}-\mathrm{f}$ \\
\hline DZ20-E6 & $0.58 \mathrm{c}-\mathrm{e}$ & $45.63 \mathrm{a}$ & $18.43 \mathrm{a}$ & $61.50 \mathrm{j}$ & 83.25 a & $35.97 \mathrm{ab}$ & $51.84 \mathrm{ab}$ \\
\hline DZ20-E7 & $0.66 \mathrm{ab}$ & $41.97 \mathrm{a}-\mathrm{d}$ & $14.38 \mathrm{~g}-1$ & $62.52 \mathrm{fg}$ & $80.61 b-e$ & $28.68 \mathrm{~d}$ & $49.15 \mathrm{a}-\mathrm{d}$ \\
\hline DZ20-E8 & $0.62 \mathrm{a}-\mathrm{c}$ & 39.90 a-e & $16.07 \mathrm{~b}-\mathrm{d}$ & $62.71 \mathrm{ef}$ & 82.80 a & $31.90 \mathrm{~b}-\mathrm{d}$ & 52.22 a \\
\hline DZ20-E9 & $0.53 \mathrm{e}$ & $37.77 \mathrm{~b}-\mathrm{e}$ & 13.73 I & $63.45 \mathrm{ab}$ & $81.35 \mathrm{a}-\mathrm{d}$ & $28.24 \mathrm{~d}$ & $39.11 \mathrm{~g}$ \\
\hline DZ20-E10 & $0.65 \mathrm{ab}$ & 38.77 a-e & $15.12 \mathrm{e}-\mathrm{g}$ & $63.00 \mathrm{c}-\mathrm{e}$ & $80.05 \mathrm{c}-\mathrm{g}$ & $29.84 \mathrm{~cd}$ & $50.62 \mathrm{a}-\mathrm{d}$ \\
\hline DZ20-E11 & $0.61 \mathrm{a}-\mathrm{d}$ & $42.90 \mathrm{a}-\mathrm{d}$ & $14.65 \mathrm{f}-1$ & $62.10 \mathrm{~h} 1$ & $79.15 \mathrm{e}-1$ & $36.64 \mathrm{a}$ & $50.78 \mathrm{a}-\mathrm{d}$ \\
\hline DZ20-E12 & $0.55 \mathrm{de}$ & $40.03 \mathrm{a}-\mathrm{e}$ & $14.74 \mathrm{f}-\mathrm{h}$ & 61.861 & 83.17 a & $29.41 \mathrm{~cd}$ & $48.65 a-d$ \\
\hline DZ20-E13 & $0.57 \mathrm{c}-\mathrm{e}$ & $43.23 \mathrm{a}-\mathrm{d}$ & $14.40 \mathrm{~g}-1$ & $63.73 \mathrm{a}$ & 82.91 a & $28.86 \mathrm{~cd}$ & $47.55 \mathrm{c}-\mathrm{f}$ \\
\hline DZ20-E14 & $0.60 \mathrm{~b}$-e & $37.40 \mathrm{~b}-\mathrm{e}$ & $13.91 \mathrm{~h} 1$ & $61.36 \mathrm{j}$ & $78.27 \mathrm{~g}-1$ & $28.91 \mathrm{~cd}$ & 44.22 ef \\
\hline DZ20-E15 & $0.63 \mathrm{a}-\mathrm{c}$ & $37.67 \mathrm{~b}-\mathrm{e}$ & $16.09 \mathrm{~b}-\mathrm{d}$ & $62.69 \mathrm{ef}$ & $82.05 \mathrm{a}-\mathrm{c}$ & $31.36 \mathrm{~cd}$ & $51.48 \mathrm{a}-\mathrm{c}$ \\
\hline DZ20-E16 & $0.60 \mathrm{~b}-\mathrm{d}$ & $37.00 \mathrm{c}-\mathrm{e}$ & $15.41 \mathrm{c}-\mathrm{f}$ & $62.00 \mathrm{~h}_{1}$ & 80.47 b-f & $31.31 \mathrm{~cd}$ & $51.28 \mathrm{a}-\mathrm{c}$ \\
\hline Ceyhan-99 & $0.65 a b$ & $36.07 \mathrm{de}$ & $14.92 \mathrm{fg}$ & $63.12 \mathrm{~b}-\mathrm{d}$ & $79.56 \mathrm{~d}-\mathrm{h}$ & $30.41 \mathrm{~cd}$ & $47.87 \mathrm{~b}-\mathrm{e}$ \\
\hline Dinç & $0.63 \mathrm{a}-\mathrm{c}$ & $34.43 \mathrm{e}$ & $14.66 \mathrm{f}-1$ & $62.20 \mathrm{gh}$ & $82.11 \mathrm{ab}$ & $30.24 \mathrm{~cd}$ & $51.27 \mathrm{a}-\mathrm{c}$ \\
\hline Empire & $0.66 \mathrm{ab}$ & $44.20 \mathrm{a}-\mathrm{c}$ & $16.27 \mathrm{bc}$ & $62.91 \mathrm{de}$ & $81.22 \mathrm{a}-\mathrm{d}$ & $31.40 \mathrm{~cd}$ & $51.80 \mathrm{ab}$ \\
\hline Pehlivan & 0.67 a & $45.33 \mathrm{a}$ & $14.76 \mathrm{f}-\mathrm{h}$ & $63.42 \mathrm{ab}$ & $77.76 \mathrm{~h}-\mathrm{j}$ & $30.72 \mathrm{~cd}$ & 49.76 a-d \\
\hline Ortalama & 0.61 & 40.31 & 15.23 & 62.37 & 80.42 & 30.97 & 49.05 \\
\hline LSD & $0.06 * *$ & $7.37 *$ & $0.92 * *$ & $0.32 * *$ & $2.04 * *$ & $4.52 *$ & $4.12 * *$ \\
\hline
\end{tabular}

Çalışmada ele alınan genotiplere ait SPAD (klorofil miktarı) değerleri 34.43 ile 45.67 arasında değişim gösterirken, kullanılan genotiplerin ortalama SPAD değeri 40.31 olarak belirlenmiştir. SPAD değeri bakımından 
en yüksek değer DZ20-E2 (45.67) ve DZ20-E6 (45.63) genotiplerinde ve en düşük değer Dinç (34.43) kontrol çeşidinde gözlemlenmiştir. Bitkilerin klorofil içeriğinin yüksek olması arzu edilmektedir. Son yıllarda çok kullanılan bu özelliğin seleksiyon kriteri olarak sslah programlarında yer alarak verimde ilerleme sağladığı bildirilmektedir [16, 34, 35]. Benzer bir çalışmada bitkiler başaklanma döneminde iken yapılan ölçümde ortalama SPAD değerinin anaçlarda 46.1, $\mathrm{F}_{1}$ melezlerinde ise 46.8 olduğunu, bitkiler erken hamur olum döneminde iken yapılan ölçümde ise ortalama SPAD değerinin anaçlarda 50.6, $\mathrm{F}_{1}$ melezlerinde ise 58.0 olduğunu bildirmişlerdir. Genotiplerin klorofil miktarının bitkinin gelişim safhalarına göre farklılışabileceği, bu yüzden erken bir dönemde ölçülen düşük klorofil içeriği ileri dönemlerde artabileceği ve bu yüzden spad ölçümüne dayalı seleksiyonun tek ölçüm bazlı değil birden fazla dönemde yapılmasının yararlı olabileceğini bildirmişlerdir [17].

Çalışmada kullanılan genotiplere ait protein oranı değerleri \% 13.73(DZ20-E9) -18.43 (DZ20-E6) arasında değişim gösterirken, ortalama protein oranı değeri \% 15.23 olarak tespit edilmiştir. Tanede protein miktarı çevre şartlarından, yetiştirme tekniğinden ve çeşidin genetik özelliklerinden etkilenmektedir. Yüksek protein miktarına sahip buğday taneleri genelde daha sert bir tane yapısına sahip olup protein miktarından doğrudan etkilenen diğer kalite özelliklerini de olumlu yönde etkilemektedir. Bazı araştırıcılara göre buğday tanesinde protein içeriği \% 8 ile 18 arasında değişebilirken [18], bazı kaynaklara göre buğday tanesinde protein içeriği \% 25 [19] oranına kadar çıkabilmektedir.

Genotiplerin nişasta oranı değerleri \% 61.36(DZ20-E14) -63.73 (DZ20-E13) arasında değişim göstermiş ve deneme ortalaması 62.37 olarak tespit edilmiştir. Nişasta oranının artan protein oranı ile genel olarak bir azalma gösterdiği ve yüksek protein içeriğine sahip genotiplerin nişasta oranının düşük olduğu saptanmıştır. Mahla ve ark., 2015 [20] tarafından yapılan çalışmada nişasta oranının genotipe ve bitkinin yetiştirme şartlarına göre farklılık gösterdiğini bildirmiştir. Çalışmadan elde edilen bulgular Mut ve ark. (2017)'nın [21] elde ettiği bulgular (\% 61.6-65.0) ile benzerlik göstermektedir.

Genotiplere ait hektolitre ağırlı̆̆ 1 değeri $75.93-83.25 \mathrm{~kg} / \mathrm{hl}$ arasında değişim göstermekte olup, denemeye ait ortalama hektolitre ağıllı̆̆ değeri $80.42 \mathrm{~kg} / \mathrm{hl}$ olarak tespit edilmiştir. İncelenen genotipler arasında maksimum hektolitre ağırlığı değeri DZ20-E6 (83.25 kg/hl), DZ20-E8 (82.80 kg/hl), DZ20-E12 (83.17 kg/hl) ve DZ20-E13 (82.91 kg/hl) hatlarından, minimum hektolitre ağıllı̆̆ değeri ise $75.93 \mathrm{~kg} / \mathrm{hl}$ ile DZ20-E4 hatından elde edilmiştir. Hastalık, zararlı ve yatma gibi çevresel etmenlerin yanı sıra başakta başakçık ve tane sayısı gibi verim öğeleri de hektolitre ağırlığını etkilemektedir [22]. Bu çalışmadan elde edilen bulgular Mut ve ark. (2007)'nın[23] ekmeklik buğday genotiplerinin verim ve kalite özellikleri üzerine yaptıkları çalışmalarında, hektolitre bakımından çeşitler arasında farklılık olduğunu bildiren bulguları ile (76.1-81.4kg/hl) uyum göstermektedir.

Araştırmada genotiplere ait elde edilen yaş gluten değerleri \% 28.24 (DZ20-E9)-36.64 (DZ20-E11) arasında değişim gösterirken, denemeye ait ortalama yaş gluten oranı değeri \% 30.97 olarak belirlenmiştir.Ekmeklik unlarda gluten proteinleri hamurun kabarması ve elastikiyeti açısından önemli bileşenlerdendir.İyi kalitede hamur elde etmek için unlarda yaş glutenin $\% 28$ 'in üzerinde olması istenmektedir [24].Çalışmada genotiplere ait ortalama gluten oranları standart değerin üzerinde yer almaktadır.Daha once yapılan benzer çalışmalarda, Egesel ve ark.(2009) [25], 1.yıl yaş gluten oranı ortalamasını $\%$ 33.1, 2. yılda ise \% 34.6; Kızlıgeçi ve Yıldırım (2019)[26],1. yıl \% 29.84, 2. yıl ise \% 43.07 olarak saptamışlardır.

Zeleny sedimantasyon değeri bakımından genotiplerden elde edilen değerler 39.11 ile $52.22 \mathrm{ml}$ arasında değişim gösterirken, deneme ortalaması $49.05 \mathrm{ml}$ olarak gözlenmiştir. Çalışmada zeleny sedimantasyon değeri bakımından en yüksek değer DZ20-E8 (52.22 ml) ve DZ20-E6 (51.84 ml) hatlarından, en düşük değer ise DZ20E9 $(39.11 \mathrm{ml})$ hatından elde edilmiştir. Zeleny sedimantasyon protein kalitesinin bir göstergesi olarak kabul edilen ve sanayiciler tarafindan yaygın olarak kullanılan bir özelliktir. Aydoğan ve ark. (2013) [27], kuru koşullarda 21 ekmeklik buğday çeşidinin Zeleny sedimantasyon değerinin 19.5-62.5 ml arasında değiştiğini bildirmişlerdir.

\section{A. Biplot Analiz Sonuçları ve Grafiklerin Yorumlanması}

GGE biplot analizi, görsel olarak verilerin değerlendirilmesini ve mega-ortam tanımlamasını kolaylaştıracak şekilde çoklu çevre deneme verilerinin Genotip + Genotip x Çevre interaksiyonu grafiksel olarak göstermektedir [28, 29, 30]. 
Araştırmada incelenen özelliklerin genotiplere göre sınıflandırılması Şekil 2'de verilmiştir. Bu çalışmada scatter biplot yöntemi ile yapılan analizde PC1 \% 38 ve PC2 \% 24.2, toplam varyasyonun \% 62.2'sini oluşturmuştur. Genotiplere göre özelliklerin sınıflandırma grafiği, temel olarak 5 mega-çevreden oluşmuştur. Bir GGE biplotunun "hangisi nerede ön plana çıktı (which-won-where)" çokgen görünümü, genotip ve özellik arasındaki ilişkinin modellerini görselleştirmenin etkili bir yoludur (Şekil 2).Çokgen köşeleri, biplot merkezinden maksimum uzakta olan genotipleri temsil etmektedir. Biplotu, mega çevreye bölen çizgiler bir dizi varsayımı temsil eder. Çokgenin açısal bir tepe noktasında yer alan bir genotip ve bu genotipe ait bir özellik (veya birkaç özellik) bir mega çevre içine düşerse, bu genotipin sahip olduğu özellik kapasitesinin bu özel bölgede en yüksek olduğu anlamına gelir. Bu biplotun bir başka önemli özelliği de, farklı mega ortamların olası varlığını gösteren çevresel gruplamaları göstermesidir. Bu nedenle, çalışmamızda ilk mega çevre, yüksek SPAD, protein, sedimantasyon ve yaş glüten özellikleri ile DZ20-E6 genotipinden oluşur. NDVI değeri ile DZ20-E4 genotipi farklı bir grup; nişasta değeri ile DZ20-E9 ve DZ20-E13 genotipleri ise başka bir mega bölgeyi oluşturur. Ayrıca, DZ20-E13 genotipi hem nişasta hem de hektolitre değeri bakımından en yüksek değere sahip genotip olarak ön plana çıkmıştır.

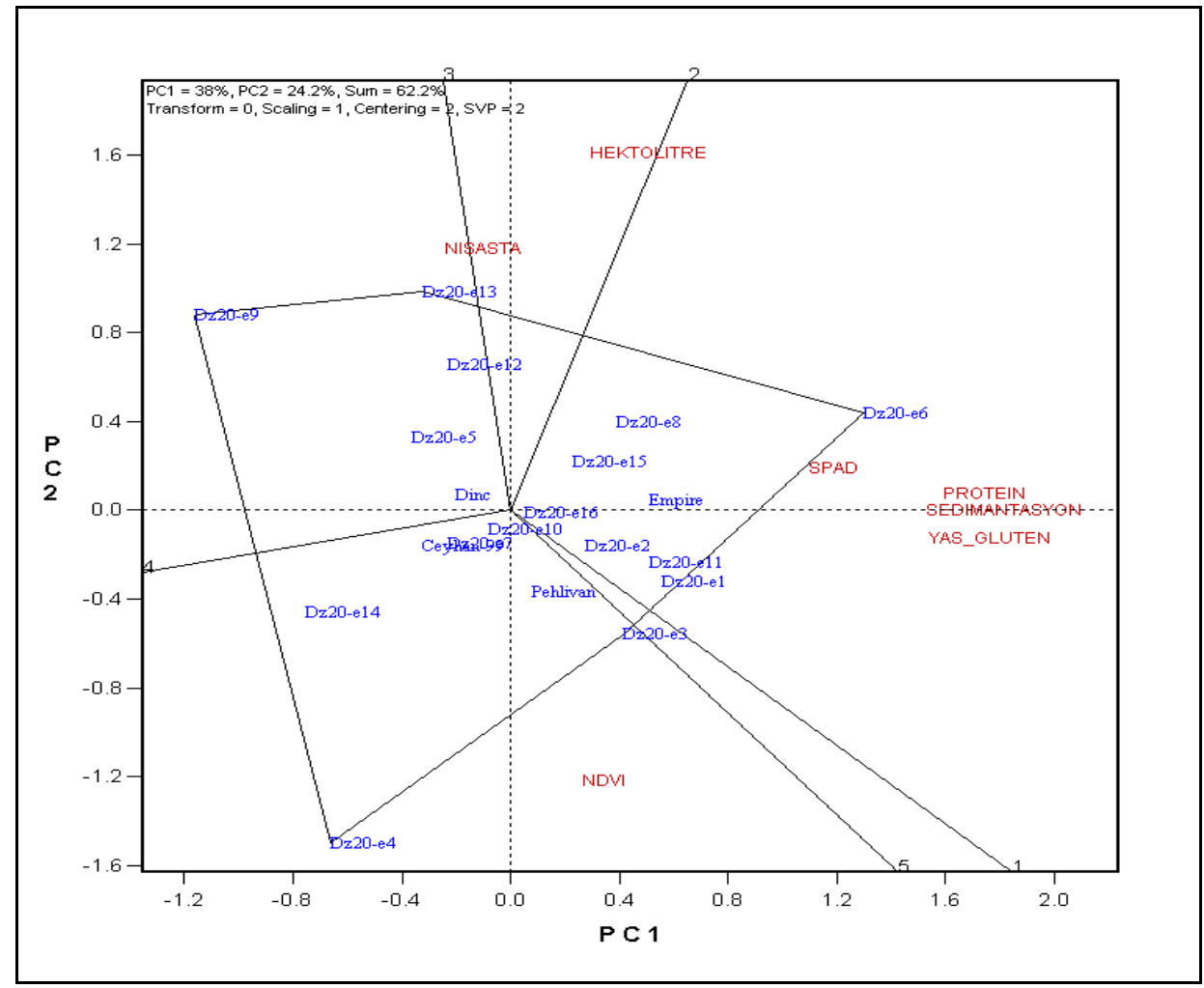

Şekil 2. Genotip ve özelliklerin "hangisi nerede ön plana çıktı (which-won-where)" GGE biplotunun çokgen modeli 


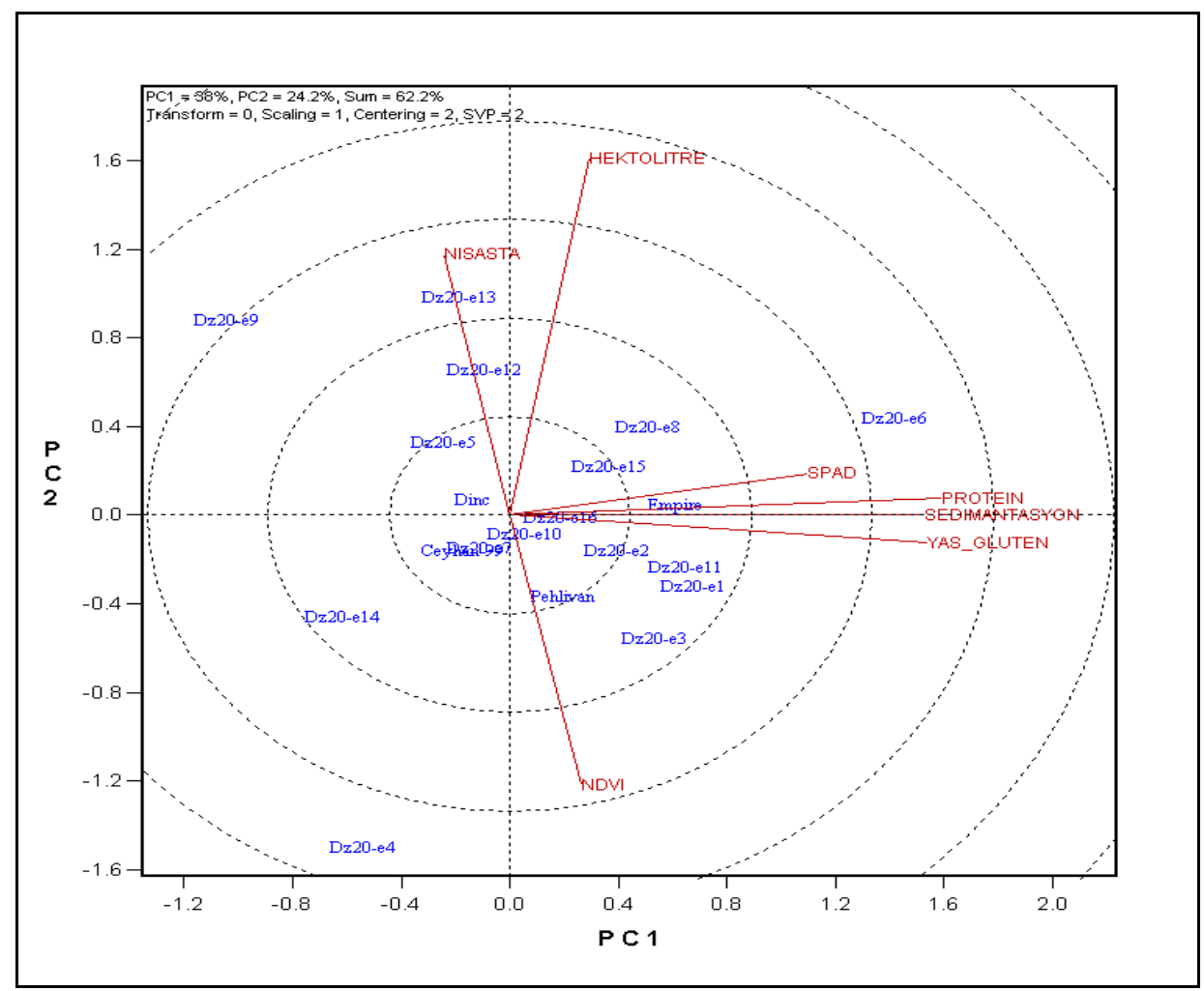

Şekil 3. Scatter biplot yöntemi ile eş merkezli daireler içerisinde özellikler arasındaki ilişkilerin gösterilmesi

Özelliklere ait vektör uzunlukları, genotiplerin eş merkezli daireler içerisindeki konumları, genotip * özellik ilişkisini ve özellikler arası ilişkileri gösteren Scatter biplot grafiği Şekil 3'de verilmiştir.Özelliklere ait vektör uzunluklarının orjine olan uzaklığı incelenen özelliğin genotipler bazında stabilitesini vermektedir.Şekil 2'de de görüldüğü gibi nişasta, SPAD ve NDVI özellikleri diğer incelenen özelliklere kıyasla daha kısa vektör uzunluklarına sahip oldukları için daha stabildir.Vektör uzunlukları arasındaki açılar özelliklerin birbirleri ile olan ilişkilerini göstermektedir.İki vektör arasındaki açı daraldıkça özellikler arasındaki ilişkinin güçlü olduğunu; geniş açıya sahip vektörler ise özellikler arasındaki ilişkinin zayıflığını göstermektedir.Vektörel olarak dar açıya sahip SPAD, protein, sedimantasyon ve yaş glüten özelliklerinin arasındaki ilişkinin güçlü olduğunu göstermektedir. Aynı şekilde vektörel olarak dar açıya sahip nişasta ve hektolitre özellikleri de kendi aralarında güçlü bir ilişkiye sahipken ters tarafta yer alan NDVI değeri bu iki özellik ile negatif korelasyon göstermektedir (Tablo 2). Aynı yöne ve aynı daire içerisinde yer alan genotipler birbirilerine yakın değerlere sahip olduğu söylenebilir [31]. 


\begin{tabular}{|c|c|c|}
\hline & $\begin{array}{l}\text { BŞEÜ Fen Bilimleri Dergisi } \\
8(1), 32-41,2021\end{array}$ & $\begin{array}{r}\text { BSEU Journal of Science } \\
\text { https://doi.org/10.35193/bseufbd.824421 }\end{array}$ \\
\hline & & 2458-7575 (https://dergipark.org.tr/tr/pub/bseufbd) \\
\hline
\end{tabular}

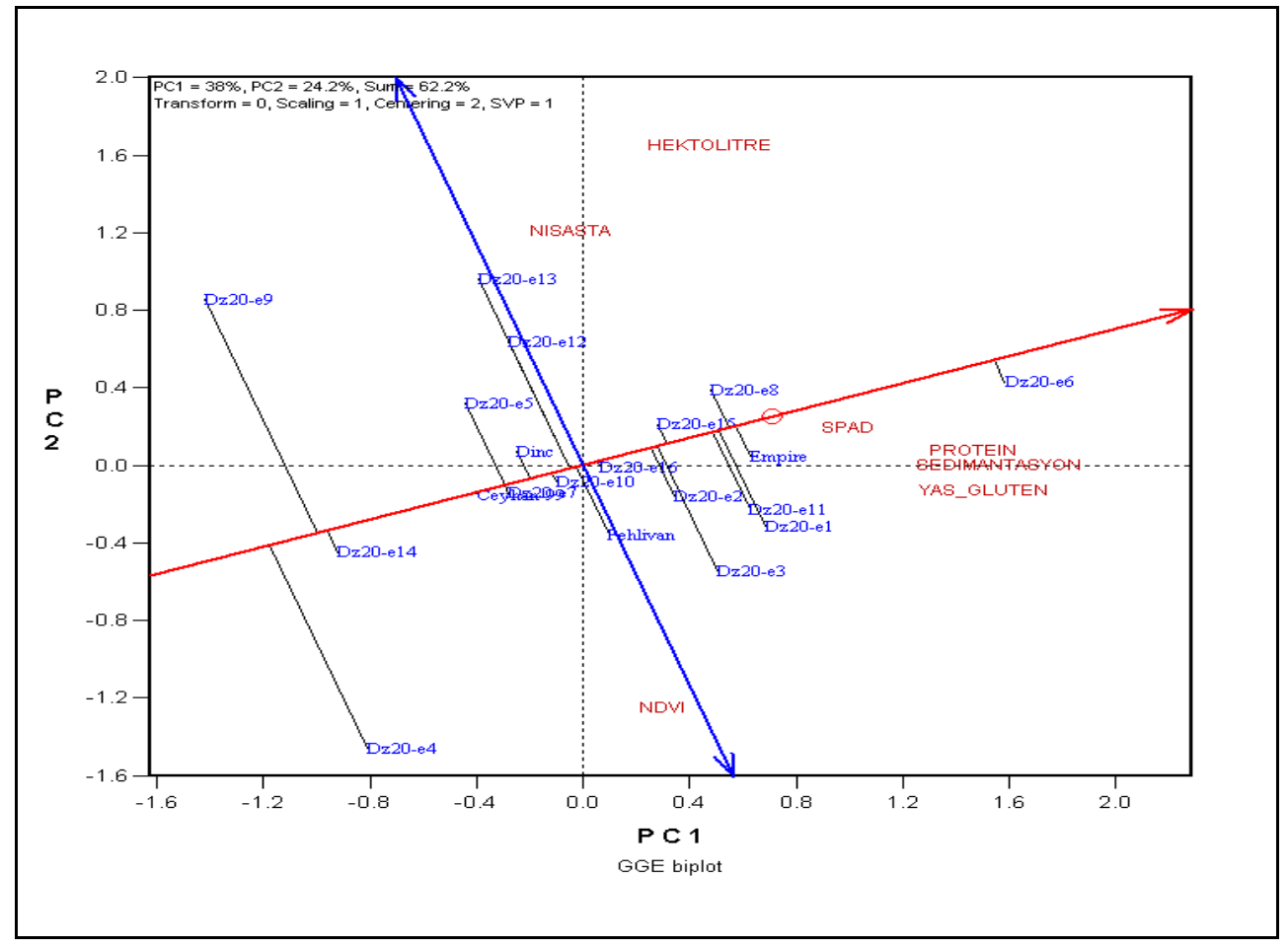

Şekil 4. Ranking biplot yöntemi ile incelenen özellikler bakımından genotiplerin stabilitesi

İdeal genotip, hem yüksek ortalamaya hem de yüksek stabiliteye sahip olan genotiptir. Ranking biplot yöntemi,genotipleri çok sayıda özelliklerin ortalamaları ve stabiliteleri ile bir doğru üzerinde sıralar (Şekil 4). Ortalamalara ait x ekseni (performans çizgisi), çift eksenli orijinden, eksenin pozitif ucunu gösteren bir okla keser ve genotipleri performanslarına göre sıralar. Çift eksenli orijinden geçen stabilite ekseni ise, ortalamalara ait x eksenine diktir. Genotiplerin ortalama kapasiteleri, belirteçlerinin x eksenine izdüşümleri ile tahmin edilir. DZ20-E6, DZ20-E8 ve Empire genotipleri en yüksek ortalama değerlere sahipken, DZ20-E4, DZ20-E9 ve DZ20-E14 genotipleri ise incelenen özelliklere ait en düşük değere sahip genotiplerdir.Ceyhan-99, DZ20-E7, DZ20-E10, DZ20-E15 ve DZ20-E16 genotipleri stabil genotipler; DZ20-E9 ve DZ20-E4 genotipleri ise stabil olmayan genotipler olarak ön plana çıkmıştır. Benzer sonuçlar daha önce GGE Biplot'ta çalışma yapan araştırmacılar tarafından da ifade edilmiştir $[32,33]$.

Özellikler arası korelasyon ilişkisinde SPAD değeri ile protein ve sedimantayon değerleri,NDVI ile sedimantasyon değerleri arasında pozitif yönlü ve önemli; NDVI ile hektolitre değeri arasında negatif yönlü ancak önemli ilişkiler saptanmıştır (Tablo 2) Elde edilen korelasyon analizi sonuçları GGE Biplot analizi sonuçlarını destekler niteliktedir.

Tablo 2. Özellikler arası korelasyon ilişkisi

\begin{tabular}{|c|c|c|c|c|c|c|}
\hline & NDVI & SPAD & Protein & Nişasta & Hektolitre & Yaş Gluten \\
\hline SPAD & 0,05 & & & & & \\
\hline Protein & 0,09 & $0,33^{*}$ & & & & \\
\hline Nişasta & $-0,04$ & 0,05 & $-0,19$ & & & \\
\hline Hektolitre & $-0,28^{*}$ & $-0,07$ & 0,17 & $0,38 * *$ & & \\
\hline Yaş Gluten & 0,04 & 0,18 & $0,52^{* *}$ & $-0,13$ & 0,08 & \\
\hline Sedimantasyon & $0,26^{*}$ & $0,36^{* *}$ & $0,66^{* *}$ & $-0,01$ & 0,1 & $0,44 * *$ \\
\hline
\end{tabular}

\section{SONUÇ}

Araştırma neticesinde incelenen özellikler bakımından genotipler arasında istatistiksel farklılıklar olduğu ve hatların gerek fizyolojik özellikler bakımından gerekse incelenen kalite özellikleri bakımından geniş bir varyasyona sahip olduğu gözlemlenmiştir.Fizyolojik ve kalite özellikleri bakımından DZ20-E6 genotipinin 
standart çeşitlere ve diğer hatlara üstünlük sağladığı belirlenmiştir.SPAD değerin protein, yaş glüten ve sedimantasyon ile ilişkili bulunması, kalite yönünden seleksiyon kriteri olabileceğini göstermektedir.

\section{KAYNAKLAR}

[1] FAO. (2018). World Total Cereal Production. http://www.fao.org/faostat/en/\#data/QC.

[2] Türkiye istatistik kurumu. (2018). Bitkisel Üretim İstatistikleri. https://data.tuik.gov.tr/Kategori/GetKategori?p=tarim-111\&dil=1.

[3] Cabrera-Bosquet, L., Molero, G., Stellacci, A., Bort, J., Nogués, S. \& Araus, J. (2011). NDVI as a potential tool for predicting biomass, plant nitrogen content and growth in wheat genotypes subjected to different water and nitrogen conditions. Cereal Res. Commun. 39,147-159.

[4] Mkhabela, M.S., Bullock, P., Raj, S., Wang, S., \& Yang, Y. (2011). Crop yield forecasting on the Canadian prairies using MODIS NDVI data. Agric. For. Meteorol. 151, 385-393.

[5] Bavec, F., \& Bavec, M. (2001). Chlorophyll meter readings of winter wheat cultivars and grain yield prediction. Commun. Soil Sci. Plant Anal. Res., 32, 2709-2719.

[6] Yan, W., \& Tinker, N. A. (2006). Biplot analysis of multi-environment trial data: Principles and applications. Can. J. Plant Sci. 86, 623-645.

[7] Rouse, J. W., Haas, R. H., Schell, J. A., \& Deering, D. W. (1973). Monitoring vegetation systems in the Great Plains with ERTS. In 3rd ERTS Symposium, NASA SP-351 I, 309-317.

[8] Osborne, B.G. (2006). Applications of near infrared spectroscopy in quality screening of early-generation material in cereal breeding programmes. J. Near Infrared Spectrosc, 14, 93-101.

[9] Silva, C. F. L., Milach, S. C. K., Silva S. D. A., \& Montero. C. R. (2008). Near infrared reflectance spectroscopy (NIRS) to assess protein and lipid contents in Avena sativa L. Crop Breed. Appl. Biotechol., 8, $127-133$.

[10] Peterson, R. G. (1994). Agricultural Field Experiments Desin and Analysis. Marcel Dekker.Inc. 409 p. Corvallis. Oregon.

[11] Yan, W., Hunt, L. A., Sheng, Q., \& Szlavnins., Z. (2000). Cultivar evaluation and mega-environment investigation based on the GGE biplot. Crop Science, 40, 597-605.

[12] Kızılgeçi, F., Yıldırım, M., \& Hossain, A. (2019). Evaluation of growth, yield, quality and physiological parameters of eleven Australian bread wheat (Triticum aestivum L.) cultivars grown under the ecological condition of Diyarbakir, Turkey. Int. J. Agric. Environ. Food Sci., 3(1), 34-40.

[13] Crusiol, L. G. T., Carvalho, J. de F. C., Sibaldelli, R. N. R., Neiverth, W., Rio, A. do, Ferreira, L. C., Procópio, S. De O., Mertz-Henning, L. M., Nepomuceno, A. L., Neumaier, N., \& Farias, J. R. B. (2017). NDVI variation according to the time of measurement, sampling size, positioning of sensor and water regime in different soybean cultivars. Precis. Agric., 18, 470.

[14] Kızılgeçi, F., Akıncı, C., Albayrak, Ö., \& Yıldırım, M. (2017). Tritikale hatlarında bazı fizyolojik parametrelerin verim ve kalite özellikleriyle ilişkilerinin belirlenmesi. I $\breve{g} d \imath$ r Üniversitesi Fen Bilimleri Enstitüsü Dergisi, 7(1), 337-344.

[15] Kızılgeçi, F., \& Yıldırım, M. (2019). Durum buğdayın başaklanma dönemine ait bazı fizyolojik ölçümlerin verim ve kalite özellikleriyle ilişkilerinin belirlenmesi. Türk Tarım ve Doğa Bilimleri Dergisi 6(4), 777785.

[16] Yıldırım, M., Bahar. B., Yücel, C., \& Genç, İ. (2009a). Cimmyt buğday verim denemesi setlerinde bitki sıcaklığı değişimleri. Türkiye VIII. Tarla Bitkileri Kongresi, 19-22 Ekim, Hatay, 427-432.

[17] Yıldırım, M., Akıncı, C., Koç, M., \& Barutçular, C. (2009b). Bitki örtüsü serinliği ve klorofil miktarının makarnalık buğday ıslahında kullanım olanakları. Anadolu Tarım Bilimleri Dergisi, 24(3), 158-166.

[18] Christen O. (2009). Winterweizen, das Handbuch fur Profis, 383 s., DLG Verlag, Frankfurt, Almanya.

[19] Gooding M. J., \& Davies W. P. (1997). Wheat production and utilization, CAB International, Wallingford.

[20] Mahla, R., Madan, S., Munjal, R., \& Hasija, R. J. (2015). Drought stress induced changes in quality and yield parameters and their association in wheat genotypes. Environment and Ecology, 33(4), 1639-1643.

[21] Mut, Z, Erbaş, K. Ö. D. \& Akay, H. (2017). Bazı ekmeklik buğday (Triticum aestivum L.) çeşitlerinin tane Verimi ve kalite özelliklerinin belirlenmesi. Anadolu Tarım Bilimleri Dergisi, 32, 85-95.

[22] Schuler, S. F., Bacon, R. K. \& Gbur, E. E. (1994). Kernel and spike character influence on test weight of soft red winter wheat. Crop Sci. 34, 1309-1313. 
[23] Mut, Z., Aydın, N., Bayramoğlu, N.O. \& Özcan, H. (2007). Bazı ekmelik buğday (Triticum aestivum L.) genotiplerinin verim ve başlıca kalite özelliklerinin belirlenmesi. OMÜ Ziraat Fakültesi Dergisi, 22(2), 193-201.

[24] Erekul, O., Oncan, F., Erekul, A., Yava, İ., Engün, B. \& Koca, Y. O. (2005). İleri ekmeklik buğday hatlarında verim ve bazı kalite özelliklerinin belirlenmesi. Türkiye VI. Tarla Bitkileri Kongresi, 5-9 Eylül, Antalya, I, 111-116.

[25] Egesel, C.Ö., Kahrıman, F., Tayyar, Ş. \& Baytekin, H. (2009). Ekmeklik buğdayda un kalite özellikleri ile dane veriminin karşılıklı etkileşimleri ve uygun çeşit seçimi. Anadolu J. Agric. Sci., 24(2), 76-83.

[26] Kızılgeçi, F. \& Yıldırım, M., 2019. Durum buğdayın başaklanma dönemine ait bazı fizyolojik ölçümlerin verim ve kalite özellikleriyle ilişkilerinin belirlenmesi. Türk Tarım ve Doğa Bilimleri Dergisi, 6(4), 777785, 2019.

[27] Aydoğan S., Göçmen Akçacık, A., Şahin, M., Önmez, H., Demir, B. \& Yakışır, E. (2013). Ekmeklik buğday çeşitlerinde fizikokimyasal ve reolojik özelliklerin belirlenmesi. Tarla Bitkileri Merkez Araştırma Enstitüsü Araştırma Dergisi, 22 (2), 74-85.

[28] Yan, W. \& Rajcan, I. (2002). Biplots analysis of the test sites and trait relations of soybean in Ontario. Crop Science 42, 11-20.

[29] Yan, W., Kang, M.S., Ma, B., Woods, S., \& Cornelius, P.L. (2007). GGE biplot vs. AMMI analysis of genotype-by-environment data. Crop Science 47, 643-655.

[30] Yan, W. (2014). Crop variety trials: Data management and analysis. John Wiley and Sons Inc., New York, 349.

[31] Kendal, E. \& Sener, O. (2015). Examination of genotype environmentinteractionsby GGE biplot analysis in spring durum wheat, Ind. J. of Genet. and Plant Breed, 75(3), 341-348.

[32] Kendal, E., Tekdal, S., Aktaş, H., Karaman, M., Berekatoğlu, K. \& Doğan, H. (2014). Biplot analizi kullanılarak yazlık arpa genotiplerinin verim ve verim unsurlarının belirlenmesi. Trakya University Journal of Natural Sciences, 15(2), 95-103.

[33] Solonechnyi, P., Vasko, N., Naumov A., Solonechnaya, O., Vazhenina, O., Bondareva, O. \& Logvinenko, Y. (2015). GGE biplot analysis of genotype by environment interaction of spring barley varieties. Zemdirbyste-Agriculture, 102(4), 431-436.

[34] Bayhan, M., Özkan, R., Albayrak, Ö., Yıldırım, M. \& Akıncı, C. (2019). Aşırı kurak sezonda ekmeklik buğday genotiplerinin performanslarinin test edilmesi. 2. Uluslararasi Mardin Artuklu Bilimsel Araştirmalar Kongresi. 23-25 Ağustos, Mardin, 162-169.

[35] Albayrak, Ö., Bayhan, M., Yıldırım, M. \& Akıncı, C. (2020). Comparison of some bread wheat (Triticum aestivum L.) lines for yield in Diyarbakir conditions. 9th. International Conference on Mathematics, Engineering, Natural and Medical Sciences. 23-26 January, Marrakech, Morocco, 36-42. 